reflecting surface produces a heterodyne whistle on the lower frequency side of the carrier wave.

The only known phenomenon with which sufficiently high velocities are associated and which could cause a Doppler effect of this nature is a meteor entering the earth's upper atmosphere, and confirmation of this was obtained by observations in the early morning hours when the appearance of meteors in the sky coincided with the heterodyne whistle produced in a receiver. The article discusses briefly the number, size, height, and velocity of meteors, the mode of dissipation of meteor energy, and meteor ionization, remarking that the summary provided of some of the known properties of meteors gives ample confirmation of the experimental evidence and deduction that the weak heterodyne whistles observed are due to the Doppler effect caused by the rapidly moving ionized area produced by a meteor. It is evident that, $(a)$ the ionization produced by meteors can be sufficient to reflect waves of the frequencies concerned, (b) the number of whistles observed is at a maximum in the early morning when the number and velocity of meteors entering the earth's atmosphere is greatest, and (c) the velocity of meteors, determined by visual means, is of the same order as that calculated from the Doppler effect observed.

The article concludes with descriptions of the experimental procedure adopted and the results obtained.

\section{NEW DESCRIPTIONS OF SOME INDIAN PLANTS}

COME interesting botanical notes have recently $\checkmark$ been given by Dr. N. L. Bor, forest botanist, Forest Research Institute, Dehra Dun (Indian For. Rec., Botany, 2, Nos. 2, 3 and 4; Govt. of India Press, Delhi, 1941).

In No. 2 the bamboo Thyrsostachys Oliveri Gamble is dealt with. This species, the author writes, flowered in the Katha district, Upper Burma, in 1891. Specimens were sent by J. W. Oliver, conservator of forests, to the late Mr. Gamble, who published a description under the above name in the Annals of the Royal Botanic Garden, Caleutta, in 1896. Seeds of the species were also sent and these were planted at Dehra Dun in several places, and also in the Royal Botanic Garden, Calcutta. All those who have known Dehra Dun during the last forty years will remember the magnificent clumps of this bamboo. All the Dehra clumps commenced to flower towards the end of November 1938, the first indication being the fading of the leaves. which soon began to fall off. In the first week of December the flowering shoots, pale purple in colour, were quite evident, and by December 12 the lower sheaths of the flowering shoots were beginning to show the tip of an emerging spikelet. By December 23 two spikelets had completely emerged from each sheath, and the six stamens, pendulous at the ends of long filaments, were visible from each of the three florets of the spikelets. Seed was ripe by January 31,1939 . Dr. Bor says that with fresh material to work upon and unlimited quantities of it, it became evident that the description given by Gamble, prepared from dried material, required modification in several respects.

A lapse of twenty-four hours is quite sufficient for the features of the structure of the delicate palea to be lost, and no amount of boiling will restore them. This fresh material enabled a revised description to be drawn up which corrects some minor inaccuracies in Gamble's description. Two plates portray the details of the inflorescence and spikelets. This reads like a botanical romance, and foresters in Burma and botanists are likely to be equally interested.

For No. 3, Dr. Bor redescribes Dunn's Vatica Shingkeng, placing it in the genus Hopea. The original description was based on incomplete material, especially the flowers. I. H. Burkill, who accompanied the expedition into the Arbor Hills of Assam in 1911 , discovered the species. He notes: "no general flowering took place during the expedition, and it was with great difficulty that one flowering tree was found". This flowering specimen was not, however, sent to Dunn, who notes in his description "flores ignoti".

In No. 4, Dr. Bor describes three flowering plants new to science: Gleditsia assamica Bor, Garnotia puchiparensis Bor and Strobilanthes andamensis Bor. Illustrations are given of each species. Dr. Bor had collected the Gleditsia in the Aga and Naga Hills. and Sadiya in Assam without flowers or fruit. $\mathrm{He}$ received these collected in Sadiya in March 1938. It is a small deciduous tree about 10 metres in height.

The Garnotia is a grass and was found growing thickly in the clefts of a large rock just west of the Puchipara rest house, Silent Valley, Madras (alt. $3,000 \mathrm{ft}$.).

The Strobilanthes is a wiry shrub up to $60 \mathrm{~cm}$. tall, gregarious in habit. The species was collected in flower by the sylviculturist of the Dehre Institute during a visit to the Andamans. It was noted that "the species was abundant in regeneration areas on limestone rocks, growing in crowded bushes $1^{\prime}-2^{\prime}$ high".

\section{DRUG CONTROL IN INDIA}

THE problem of drug standardization and drug control in a country of the size and population of India is a vast one. In Great Britain, the United States and other progressive countries a general consciousness of the evils of food and drug adulteration on community health and national well-being was aroused nearly fifty years ago, and the authorities took up the responsibility of safeguarding public health and money by instituting adequate control of the spurious drug trade. In India, on the other hand, although the possible injurious effects of the adulteration of foods were recognized early enough, the seriousness of the situation arising out of the indiscriminate adulteration of drugs and chemicals for the treatment of diseases received comparatively little attention, and India came to be considered the dumping ground of all kinds of substandard, misbranded and poor-quality drugs and pharmaceuticals.

Realizing the need for both legislative and executive action the Drugs Enquiry Committee 1930-31, appointed by the Government of India, recommended that All-India legislation should be passed for the control of the importation, manufacture, sale and distribution of adulterated and under-strength drugs, and that machinery should be established for the regular collection and testing of drugs to ensure conformity to proper standards of purity and strength. It was suggested that for the standardization of drugs a well-equipped central laboratory should be set up with a competent staff of experts 